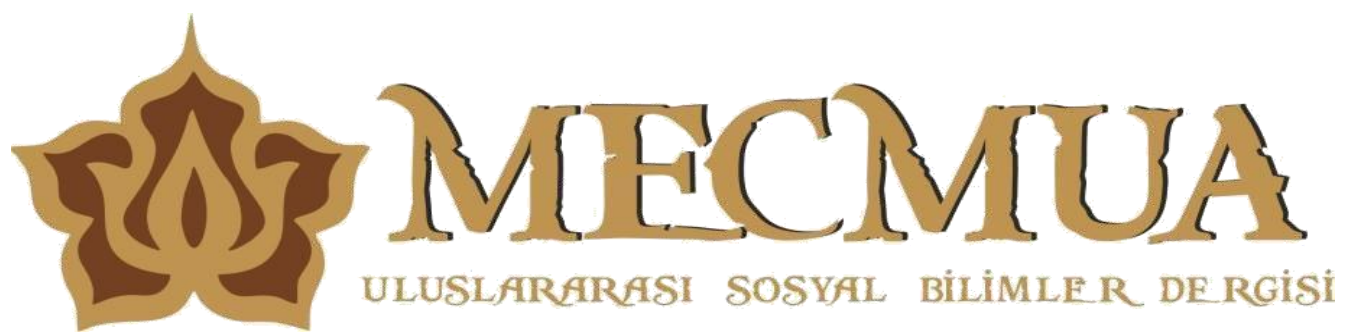

MECMUA - Uluslararası Sosyal Bilimler Dergisi [International Journal Of Social Sciences] ISSN: 2587-1811 Yıl: 5, Sayı: 10, Güz 2020

Medya Emperyalizmine Althusser'in Haberleșme Dia'sı Bağlamından Bakmak: Reuters, Ap, Upı, Afp ve Tass Üzerine Bir İnceleme
Looking At Media Imperialism From the Context of Althusser's Communication ISA: A Review On Reuters, AP, UPI, AFP, And TASS

\title{
Sinan BARAN
}

Ankara Üniversitesi, Sosyal Bilimler Enstitüsü, Gazetecilik Anabilim Dalı Doktora Öğrencisi, Ankara, Türkiye. sinan.brn@ hotmail.com

Makale Bilgisi / Article Information

Makale Türü: Araştırma Makalesi

DOI: mecmua.783672

Yükleme Tarihi: 21.08.2020

Kabul Tarihi: 22.09.2020

Yayımlanma Tarihi: 30.09 .2020

Sayı: 10

Sayfa: $395-415$
Article Information: Research Article DOI: mecmua.783672

Received Date: 21.08 .2020

Accepted Date: 22.09 .2020

Date Published: 30.09.2020

Volume: 10

Sayfa: $395-415$

\section{Atıf / Citation}

BARAN, S. (2020). Medya Emperyalizmine Althusser'in Haberleşme Dia'sı Bağlamından Bakmak: Reuters, Ap, Up1, Afp ve Tass Üzerine Bir İnceleme. MECMUA - Uluslararası Sosyal Bilimler Dergisi ISSN: 2587-1811 Y11: 5, Say1: 10, Sayfa: 395-415

BARAN, S. (2020). Looking At Media Imperialism From the Context of Althusser's Communication ISA: A Review On Reuters, AP, UPI, AFP, And TASS. MECMUA - International Journal Of Social Sciences ISSN: 2587-1811 Year: 5, Volume: 10, Page: 395-415 


\section{MEDYA EMPERYALIZMINE ALTHUSSER'IN HABERLEŞME DIA'SI BAĞLAMINDAN BAKMAK: REUTERS, AP, UPI, AFP VE TASS ÜZERİNE BİR INCELEME}

\section{Looking At Media Imperialism From The Context Of Althusser's Communication ISA: A Review On Reuters, AP, UPI, AFP, And TASS}

\section{ÖZ}

Louis Althusser 20. yüzy1lın en önemli düşünürlerinden birisidir. Geliştirdiği Devletin İdeolojik Aygitları kuramı önemini hala korumakla birlikte günümüze değin tartış1la gelmiştir. Bu makalede Louis Althusser'in Haberleşme DİA'sı çerçevesinde "emperyalizm”, “medya emperyalizmi" ve "haber ajansları" konuları irdelenmiştir. Althusser'in Devletin İdeolojik Aygitı olarak gördüğü 'Haberleşme' aslında sadece devletin değil aynı zamanda siyasal iktidarın ve özellikle de 1980 sonrası liberal ekonomiye geçişle birlikte sermaye iktidarının da bir aygıtı olarak etkili biçimde kullanılmaktadır. Dolayısıyla haberleşme kamu yararından çıktığı an bir şekilde aygıta dönüşmektedir ve bu suretle İdeolojik Aygıt olarak çalışmaktadır.

Althusser'in DİA'ları arasında 'Haberleşme' bu çalışmanın odağını oluşturmaktadır. Çalışmanın amacını Reuters, AP, UPI, AFP ve TASS'ın uluslararası çapta örgütlenmeleri sayesinde ideolojileri uluslararası düzeyde nasıl aktarabileceği üzerine teorik olarak yoğunlaşılması oluşturmaktadır. Bu amacı neticelendirmek için makale, eleştirel yöntemle araştırma yaparak tartışılmış, İngilizce ve Türkçe akademik makaleler incelenerek derleme çalışması yapılmıştır. Yapılan araştırmaya göre Althusser'in geliştirmiş olduğu Devletin İdeolojik Aygıtları kuramlarından 'Haberleşme', uluslararası haber ajansları üzerinden farklı sermaye iktidarları tarafından çeşitli yönleriyle etkin bir biçimde kullanılmaktadır. Sonuç olarak beş büyük uluslararası haber ajansının örgütlenme yapısına bakıldığında enformasyon dengesizliğinin devam ettiği söylenebilir.

Anahtar Kelimeler: Haberleşme, Enformasyon, Medya Emperyalizmi, Haber Ajansları, İdeoloji ve Devletin İdeolojik Aygitı

\begin{abstract}
Louis Althusser is one of the most important thinkers of the 20th century. The Theory of Ideological Devices of the State it has developed still maintains its importance, but has been discussed until today. In this article, the issues of "imperialism", "media imperialism" and "news agencies" are examined within the framework of Louis Althusser's Communication ISA. 'Communication', which Althusser sees as the Ideological Device of the State, is actually used effectively as a device of not only the state but also the political power, and especially capital power after the transition to the liberal economy after 1980 . Therefore, the communication turns into a device as soon as it comes out of the public interest and thus works as an ideological device.
\end{abstract}

Communication among Althusser's ISA's is the focus of this study. The aim of the study is to theoretically concentrate on how to transfer ideologies internationally, thanks to the international organization of Reuters, AP, UPI, AFP and TASS. In order to conclude this aim, the article was critically discussed by doing research, and a review study was conducted by examining academic articles in English and Turkish. According to the research, "Communication", one of the theories of the Ideological Apparatuses of the State, developed by Althusser, is used effectively by different capital powers through international news agencies. As a result, when we look at the organizational structure of the five major international news agencies, it can be said that the information imbalance continues.

Key Words: Communication, Information, Media Imperialism, News Agencies, Ideology and Ideological State Apparatuses 


\section{Giriş}

Haberleşme; geçmişten günümüze değin kritik bir işleve sahip olmuş, günümüzden geleceğe yönelik de kritik bir işleve sahip olacaktır. İnsanların toplumların aydınlatılmasında ve yöneten ile yönetilen arasında köprü vaziyetinde bulunmasında haberleşme aktif bir rol oynamıştır. Bununla birlikte gelişen teknolojiyle dünya sistemi de değişmiştir. Çeşitli ideolojiler, iktidar oyunları ve emperyalizm gibi olgularda haberleşme faaliyetleri köşe başında yer almıştır. Haberleşmenin önemine binaen Metin Kazancı'nın şu ifadeleri kayda değerdir;

"Her gün gazeteler, radyolar, televizyonlar belirli olayları halka duyuruyor. Her gün yüzlerce, binlerce haber insanların bilgisine sunuluyor. Günümüz insanı kesinlikle habersiz yaşayamıyor. İnsanların büyük bölümü haber bağımlısı. Nedir bu haber denilen olay? Acaba amacı yalnızca belirli olayları insanlara duyurmak mı? Yoksa haber örtüsünün altında başka gerekçeler başka nedenler mi yatıyor? Haberi derleyenler, yazanlar ve okuyanlar tıpkı dinleyenler, izleyenler gibi bilmeden ne tür sonuçlar yaratıyor, ne tür amaçlara hizmet ediyorlar? Kısaca insandan insana belirli mesajların iletilmesi olayının yani kitle iletişiminin altında yatan gerçek ne? Kitle iletişimi içinde haber kimilerine göre insanları yalnızca bilgilendiren, eğlendiren, eğitimine katkıda bulunan bir araç. Kimilerine göre bu olay toplumda çok şeyi etkileyen ideolojik sistemin bir bileşeni. Kimilerine göre de toplumla birey arasında etkileşimi sağlayan, birbirlerine yaklaştıran, toplumsal sorumluluk yaratan bir fenomen" (Kazanc1, 2002: 56).

Haberleşmenin uluslararası ayağını oluşturan haber ajanslarının işlevi çok daha fazladır. Çünkü dünyada her ülkenin aynı oranda güce sahip olmaması orantısız iletişime yol açmaktadır. Bu tek yönlü iletişim neticesinde enformasyon bombardımanına maruz kalan gelişmemiş ülkeler, haber içeriğiyle birlikte ideolojileri de almaktadırlar. Medyanın gündem oluşturma veya gündem değiştirme gücü göz önüne alındığında kitleleri istediği yönde düşündürme veya yönlendirme gücü vardır. Bu noktada Althusser'in İdeolojik Devlet Aygitları Kuramı dikkat çekicidir. Çünkü ideolojinin duyurulması ve meşruluk kazandırılması üstelik bunu rıza ile başarması haberleşme DİA'sının alanındadır. İnsanların celbedilmesi ve onları özneleştirerek seslenilmesi uluslararası çapta haber ajanslarının uzun yıllar tekelinde kalmıştır.

Haber, insanların hak ve hukuklarını dile ve gündeme getiren önemli bir işleve sahiptir. Fakat kazanç odaklı bir biçimde dünyayı bölgesel olarak parselleyen uluslararası haber ajanslarının sermaye iktidarlığı çerçevesinde çalıştı̆̆ görülmektedir. Örneğin uluslararası haber ajansları; 
- Kovid-19 sürecinde yaşanılan eşitsizlikleri sık sık gündeme taşımış mıdır yoksa sadece eşitsizliklere yönelik haber yapıp günü mü kurtarmıştır?

- Doğu Akdeniz bölgesinde gelişen olaylara ne kadar tarafsız bakabilmişlerdir?

- Özellikle son y1llarda yaşanılan ve tüm dünyayı etkileyen Suriyeli mültecilerin Batılı ülkelere giderken yaşadıkları insanlık dışı muameleler karşısında uğradıkları her türlü (ölüm, şiddet vb.) olayı mı haberleştirmişlerdir yoksa yaşanılan drama yönelik kamuoyu mu oluşturmuşlardır?

- Kudüs'ün mevcut durumunu sürekli ihlal eden İsrail'in ve destekçisi ABD'nin yasa dışı tutum ve icraatlarını belgelendirerek dünya kamuoyuna sunmuşlar midır?

konularında üzerine düşen görevi yerine getirme hususunda açık ara yanlı davranmaktadır. Çünkü sermaye iktidarı için yukarıda bahsedilen Kovid-19 tedavisindeki eşitsizlikler, Doğu Akdeniz meselesindeki tarafgirlik, Suriyeli mültecilerin durumu, Kudüs'ün yapısı ve bunun gibi birçok mesele sadece kâr odaklı haberlerden oluşmaktadır. Uluslararası haber ajansları dünyada olup bitenler karşısında kâr odaklı bakış açısına sahiptirler ve sahiplik yapılarının çıkarları doğrultusunda hareket etmektedirler. Uluslararası haber dengesizliği dolaysıyla eşitsiz, adaletsiz ve düzeysiz bir sisteme göz yummak anlamına da gelmektedir.

$\mathrm{Bu}$ makalede Louis Althusser'in haberleşme DİA's1 çerçevesinde uluslararası güce sahip beş büyük haber ajansın medya emperyalizmi tartışılmıştır. Geçmişte dünyayı paylaşarak enformasyon sağlayan haber ajansları, sömürgecilikle birlikte kendi ülkelerinin dini ve kültürel ideolojilerini zamanla aktarmışlardır. Öyle ki günümüzde bazı sömürge ülkelerinde bunların izi açıkça görülebilmektedir. Ayrıca çalışmada uluslararası haber ajanslarının mevcudiyetleri bakımından ne gibi tekelleşmeye, dengesizliğe ve tek sesliliğe neden oldukları/olabilecekleri sorunsalı üzerinde de durulmuştur.

\section{Devletin İdeolojik Aygitları}

İdeolojinin zemin bulması şüphesiz şartların eşit olmadığg yerde başlar. Çünkü ideoloji sistemsel olarak Devletin İdeolojik Aygıtı olan aile kurumunda yeşerir yine başka bir DİA olan okul kurumunda yetişir ve yine başka bir DİA olan haberleşme ile sürekli bir biçimde taze tutulur ve böylece üretimin yeniden üretimi sağlanmış olur. Bu dolayımla ideoloji bir nevi kendiliğinden yerleşmiş olur ve bu süreç böyle devam eder.

Fransız düşünür Louis Althusser'e (1918-1990) göre ideoloji; "toplumsal yaşantıyı farklı biçimlerde fakat her zaman ve her aşamada kendiliğinden etkileyen bir oluşumdur" (Kazanc1, 2012: 72). Devletin İdeolojik Aygitları denildiğinde ise, "gözlemcinin karşısına, birbirinden ayrı ve özelleşmiş kurumlar biçiminde dolaysız olarak çıkan belirli sayıda gerçeklik çıkar. Althusser, bu gerçekliklerin doğal olarak ayrıntılı bir incelemeyi, denenmeyi, düzeltmeyi ve yeniden düzenlenmeyi 
gerektirecek deneysel bir listesini sunmuştur. Bu gerekliğin içerdiği tüm sakıncaları göz önünde tutarak aşağıdaki kurumları DİA'ları olarak kabul eder" (Althusser, 2010: 168-169);

- Dinsel DİA (farkl1 Kiliseler 'in oluşturduğu sistem).

- Öğrenimsel DİA (farklı, gerek özel gerekse devlet okullarının oluşturduğu sistem).

- Aile DİA’s1.

- Hukuki DİA.

- Siyasal DİA (değişik partileri de içeren sistem).

- Sendikal DİA.

- Haberleşme DİA’s1 (basın, radyo-televizyon vb.).

- Kültürel DİA (edebiyat, güzel sanatlar, spor vb.).

Althusser'in yukarıda belirtilen Devletin İdeolojik Aygıtları içinde yer alan haberleşmenin çok yönlü bir işlevi vardır. Meşrulaştırma, normalleştirme ve en önemlisi de üretim ilişkilerinin yeniden üretilmesini sağlaması bu işlevlerden bazılarıdır.

“İlk kez 1970’te yayınlanan İdeolojik Devlet Aygıtı makalesinin yöntem bilimsel çıkış noktası, "üretim koşullarının" yani bir yandan meta olarak emek gücünün ve öte yandan üretim ilişkilerinin "yeniden üretimi "ne ilişkin sorundu" (Rehmann, 2015: 160). "Althusser, "yeniden üretim" kavramından yola çıkarak, bilinçlerin yeniden üretilmesi ile ideoloji kavramını açıklamaya çalışmaktadır. "Devletin İdeolojik Aygitları" şeklinde bir sinıflandırmaya gitmekte ve hangi kurumun ne şekilde yeniden üretime katıldığını açıklamaya çalışmaktadır" (Çoban, 2011: 136). Üretim ilişkilerinin yeniden üretimi büyük ölçüde devlet iktidarının devlet aygitlarında uygulanmasıyla, yani bir yandan Devletin İdeolojik Ayıtlarında, öbür yandan (baskıcı) Devlet Aygıtında uygulanmasıyla sağlanır" (Althusser, 2014: 55).

"Althusser' in ideoloji kuramı üç temel sav etrafında gelişir. Bunlardan ilk ikisi, insanların kendilerini ve gerçeklikle imgesel ilişkilerini temsil edebilmek için ideolojiye duydukları ihtiyaçla ve ideolojinin toplumsal oluşum içindeki işleyiş̧iyle ilgilidir. 'İdeoloji bireyleri özneler olarak çağırır' biçimindeki sonuncu sav ise özne kategorisi açısından önemlidir" (Çelik, 1999: 123) ve her ideoloji bir özneler kategorisi üzerine oturtulmuştur. "Özne ideolojinin kurucu kategorisidir. Çünkü bir ideoloji özne aracılığıyla belirir ve ancak özneler için vardır. Pratikte bir ideoloji aracılığıyla ideolojinin içinde vardır” (Kazanc1, 2002: 60).

Rehman, Althusser'den yola çıkarak, "genelde ideolojiyi somut bireylerin birer özne olarak oluşturulmaları işlevi aracılığıyla tanımlamıştır” (Rehmann, 
2015: 167). "Özne sözcüğünün iki anlamı vardır: denetim ve bağımlılık yoluyla başkasına tabi olan özne ve vicdan ya da öz bilgi yoluyla kendi kimliğine bağlanmış olan özne" (Foucault, 2014: 63). Althusser'e göre, ideoloji "kesinlikle bu iki karşıt anlamın birleşimi aracılığıyla işlerlik gösterir" (Rehmann, 2015: 167). Üretimin yeniden üretimi ve üretim koşullarının yeniden sağlanması için kapitalist bir evrende son kullanım tarihi olamayan ideolojinin aktif bir şekilde kullanılması, bireyleri özneleştirmesi ve bu suretle bireylerin celbedilmesiyle sistem işlemektedir. İdeolojinin işlemesinde hatta oluşturulmasında ve meşrulaştırılmasında uluslararası çalışan ve belirli bir sermaye ortaklığına sahip haber ajansları önemli bir yer tutmaktadır.

"Haber, toplumun ideolojik kurgusunun en önemli taşıdır ya da taşlarından biridir. İdeolojik oluşumun mikroorganizmaları, hücreleri haberlerden oluşmuştur" (Kazanc1, 2002: 78). "Haber aygitı, tüm 'yurttaşları' basın, radyo, televizyon ile günlük milliyetçilik, şovenizm, liberalizm, ahlakçllık vb. dozlarıyla besler" (Althusser, 2010: 179).

"Althusser medya ile ilgili herhangi bir çalışma yapmamış olmasına karşın iletişim, medya ya da söylem analizlerinde onun sorduğu sorularla yola çıkmak ve haberi onun örgüsü içinde irdelemek, çok değerli ve geçerli sonuçlar doğuracaktır" (Kazanc1, 2002: 55). "Medya bir bilgi alış-veriş aracı olarak görülmektedir ve 'bilgi-güç' ilişkisi önemli bir etken haline gelmektedir. Ancak kapitalist ülkelerde medya kapitalistlerin hizmetindedir ve bilgi, gerçekleri değil gerçek olarak görülmesi gerekenleri değerlendirmek için kullanılan bir kavram haline dönüşmüş haldedir. Bu anlamda 'bilgi' gerçekliği değil, görünmesi gereken 'gerçekliği' yani yalanları doğru haline getiren bilgi haline gelmekte ve bu bilgi medya kanallarıyla topluma dağıtılmaktadır" (Çoban, 2011: 134).

"Bilinse de bilinmese de, günümüzde haberin ideolojik sorgulaması kaynağını Althusser, Gramsci gibi düşünürlerden almaktadır. $\mathrm{Bu}$ kişilerin çalışmalarında haber ve habercilik özelinde incelemeler yoktur. Bir başka anlatımla ne Althusser ne de Gramsci medya ile ilgili çalışma yapmış ne de medyaya özel göndermelerde bulunmuşlardır. Ama bu kişiler yapıtlarında kalkış noktasını belirtmişlerdir. Günümüz medya araştırmalarında bu iki düşünürün görüşlerinden yararlanması doğru sonuçlara ulaşmak için zorunludur" (Kazanc1, 2002: 85). "Kitle iletişim araçları diğer devletin ideolojik aygıtları gibi aynı hedefe yönelmekte, üretim ilişkilerinin yeniden üretimi, yani kapitalist sömürü ilişkilerinin yeniden üretimi amacına katkı sağlamaktadırlar" (Kazaz ve Çoban, 2010: 196). Bu bağlamda orantısız bir biçimde dünyanın geneline yayılan uluslararası haber ajansları, dünyayı haber ağı ile sarmaktadır. Dengesiz ve yeterince alternatifsiz bir güçle uluslararası haber ajansları ideolojinin yerleşmesinde, yaygınlaşmasında, toplumları dönüştürme ve şekillendirmesinde etkili olmaktadırlar. 
Oluşturulan kültürün yayılmasında ise uluslararası haber akışı önemli bir işleve sahiptir. Aynı zamanda uluslararası haber akışı sayesinde ekonomik, kültürel ve enformatik iktidara sahip olma süreci temellerini insanlara okul çağında aş1lanmaktadır. Bu tür düşünceleri referans alan batı, kapitalizmin etkisiyle de yaptığ1 sömürgeciliği birçok alanda gerçekleştirmiştir. Sömürge ülkelerinin dili, dini, yaşam biçimleri ve daha pek çok yaşam pratikleri kökten tahrifata uğramıştır. Bu tahrifatta batının medya emperyalizmi önemli rol oynamıştır. Bugün Afrika'nın bir ülkesi olan Fildişi Sahili'nin resmi dili Fransızcadır. Babası Müslüman annesi Hristiyan olan Muhammed ismindeki bir kişi, dininin ne olduğu hakkında bir görüş bildirememesi nasıl özneleştirilerek ve celbedilerek yetiştiğine bir örnektir. Haber ajanslarının küreselleşmeye katkısı, ideolojiyi sınırsızlaştırması ve bizzat kendisinin bir 'haberleşme aygıtı' olarak işlev görmesi bu örnekteki gibi pek çok sorun doğurmaktadır. Bu noktada emperyalizmin kavramsal olarak ne olduğuna bakmak çalışma için yararlı olacaktır.

\section{Emperyalizm (Imperialism)}

"Sözcük olarak imperialism 19.yüzyılın ikinci yarısında gelişmiştir. Imperialist çok daha eskidir, 17. yüzyılın başlarına kadar gider ama 19. yüzyılın sonlarına kadar imparatora ya da yönetim biçimi olarak imparatorluğa bağlı olan anlamını taşımıştır. Imperial'ın kendisi, aynı eski anlamla, 14. yüzyıldan bu yana İngilizce 'de kullanılmıştır; yakın kökü Latince imperialis, kök sözcüğü ise Latince imperium emir ya da üstün güçtür. Imperialism ve modern anlamıyla imperialist önce İngilizce'de gelişmiş, özellikle 1870 'ten sonra anlamı sürekli tartış1lmıştır, çünkü örgütlü sömürge ticareti ve örgütlü sömürge yönetimine farklı gerekçeler ve yorumlar atfedilmiştir. Imperialism 20. yüzyılın başlarında, çeşitli biçimlerde modern emperyalizm olgusunu kapitalist ekonominin belli bir aşamasına bağlayan bir dizi yazarın - Kautsky, Bauer, Hobson, Hilferding, Lenin- yapıtında yeni bir özgül yan anlam kazanmıştır" (Williams, 2016: 191). "Emperyalizm, genel anlamda, kapitalizmin bazı özelliklerinin gelişimi ve doğrudan doğruya devamı olarak ortaya çıkmıştır. Ama kapitalizm, kapitalist emperyalizm haline ancak gelişmesinin belirli ve çok yüksek bir düzeyde, kapitalizmin esas özelliklerinden bazıları kendi karşıtlarına dönüşmeye başladığı zaman; kapitalizmin yüksek bir ekonomik ve toplumsal yapıya geçiş döneminin bazı ögeleri bütün gelişme çizgisi boyunca biçimlenip belirdiği zaman gelebilmiştir” (Lenin, 2003: 89).

"Emperyalizm kavramı ise, emperyal devletler ile çokuluslu şirketler tarafindan uygulanan tahakküm ve sömürüyü ve az gelişmiş devletler ile çalışan sınıflardan oluşan yığınları vurgular. Günümüz dünyasında, emperyal ülkelerin, ticaret yaptıkları üçüncü dünya ülkelerine çok daha az bağımlı oldukları açıktır: Ticareti yapılan metaların içeriğine bakıldığında, enformasyonun yoğun, üçüncü dünya ticaretini belirleyen hammaddelerin ise düşük seviyede olduğu görülür; emperyal ülkeler çeşitli arz kaynaklarına sahiptir; büyük ekonomik birimler çoğunlukla emperyal ülkelerdeki hissedarlara ait olmakta ve onlar tarafından 
işletilmektedir ve karlar, kar payları, rantlar ve faiz ödemeleri, asimetrik bir biçimde aşağı yukarı dalgalanmaktadır. Dahası, emperyal ülkeler, uluslararası mali kurumlar ve diğer uluslararası birimlerde aşırı ve belirleyici bir etkiye sahiptir" (Petras ve Yeltıneyer, 2006: 205). Uluslararası haber ajanslarının sahipliğine bakıldığında da emperyal devletlerin ellerinde oldukları açıkça görülmektedir. İleriki bölümlerde sahiplik yapıları hakkında bilgi verilen uluslararası haber ajansları, enformasyonun tek yönlü akışını tetiklemekle birlikte ideolojik zemini de hazırlamaktadır.

Emperyalizmin ilk dönemleri eski çağa dayandırılabilir. Eski çağlarda Babil, Asur, Misır, Pers, Yunan ve Roma imparatorlukları yabanc1 toprakların ele geçirilmesine ve buradaki halkın sömürülmesine dayanmaktadır. İkinci dönem (15. yy - 16. yy), Avrupa ticaret sömürgeciliğidir. Avrupalı güçler (İspanya, Britanya, Portekiz gibi) kendi donanmalarıyla denizleri denetim altına alıp başlıca ticaret merkezlerini kurdular ve bazı büyük bölgeleri de ele geçirmiştir. Bunlarla birlikte "modern emperyalizm" de denilen, emperyalist yayılmanın üçüncü dönemi, 1870'lerde başladı ve ikinci dünya savaşı bitiminde sona ermiştir. Bu dönemde Avrupalı güçler ve $\mathrm{ABD}$ arasında bir sömürgecilik yarışının sürdüğ̈̈ görülür. Büyük Britanya ve Fransa'nın yanı sıra Belçika, Almanya ve İtalya da, bu yarışta yer almışlardır (Görsel Dünya Ansiklopedisinden Akt. Dikici, 2014: 54). "Avrupa'nın hegemonik gücünün yayılmasının en önemli iki biçimi, yeni dünyanın ilkel topluluklarının yok edilerek, Avrupalı yerleşimine açılması ve Asya ve Afrika'da sömürgeler oluşturmak olmuştur. On altıncı yüzyıldan 1914'e kadar, önemli bir ekonomik birikime sahip olan Avrupa, bu birikim sayesinde ekonomik üstünlügünü II. Dünya Savaşına kadar sürdürebilmiştir. Bu tarihten itibaren dünya ekonomisi ABD'nin hegemonyası altında varlığını devam ettirmektedir" (Özyurt, 2012: 55-56).

Emperyalizm işine başlamadan önce ve başladıktan sonra muhakkak suretle sömürülecek yerde yaşayan toplumun zaten yetersiz olan bilinçleri üzerinde rızanın imal edilmesi gerekmektedir. Rızanın imalatı durumu emperyalizmin bir nevi hammaddesi olarak düşünülebilir. İdeolojinin yaygınlaştırılmasıyla rızanın imal edilmesinde çeşitli yöntemler mevcuttur. Bunlar arasında eğitim, kültürlerarası etkileşimlilik, üçüncü dünya ülkelerine yönelik geliştirilen çeşitli kalkınma projeleri ve haber ajansları dolayımıyla tek yönlü akış sıralanabilir. Kuşkusuz bu sıralananlar arasında en etkili olan haber ajanslarıdır çünkü eğitimin, kültürün ve diğerlerinin duyurulmasında ve insanların algılarında resmetmesinde haber ajansları etkilidir. Dolayısıyla bu medya emperyalizmi ile gerçekleştirilir. Althusser'in geliştirdiği Haberleşme DİA'sı bağlamında düşünüldüğünde medya istediği gibi düşündürmeye, kesintisiz propaganda yapmaya ve gerekli gördüğü takdirde de hileli yönlendirme yapmaya gücünün olduğu tarih sahnesinde çok defa görülmüşür. Buradan hareketle medya emperyalizminin ne olduğu çalışmanın yapı taşlarından birisini oluşturmaktadır. 


\section{Medya Emperyalizmi}

Rönesans’tan bu yana geçen beş yüz yıla, “Avrupa Dönemi” dense yeridir. $\mathrm{Bu}$ dönemde Asya, bir ölüm dalgınlığı içindedir. Afrika’ysa yoktur (Karakoç, 2017: 7). Rönesans'ın ortaya çıkması ve akabindeki gelişmelere binaen 17. ve 18. yüzyılda Aydınlanma Dönemi Avrupa'da başlamış etkisini günümüze değin tüm dünya hissetmiştir. Aydınlanma olarak adlandırılan dönemin kurucuları arasında yer alan René Descartes, Francis Bacon, David Hume, Immanuel Kant ve Georg Wilhelm Friedrich Hegel gibi düşünürlerle artık bilimsel bilgi gelişme göstermeye başlamıştır. Matematik biliminin gelişmesi ve deney ve gözlemin önem göstermesi bir müddet sonra İngiltere'de Endüstri Devrimine yol açmış, yeni üretim teknolojileri beraberinde yeni tüketim toplumunun zeminini hazırlamıştır. Fakat üretimin sürekliliği daha çok hammaddeye ihtiyacı doğurmuş, bunun neticesinde de Batılı devletlerin emperyalizmi hız kazanmıştır. Bazı Aydınlanma Dönemi düşünürleri bu doğrultuda emperyalizmi mübah gösterir nitelikte yazılara imza atmışlardır.

Örneğin "David Hume, 1748'de yazdığı Ulusların Karakterleri denemesinde, "Siyahlar ve öteki yaratıklar doğal olarak beyazlardan daha aşağıdır" demiştir. Immanuel Kant, 1764'te Yüce ve Güzel Olanı Hissetme Üzerine Gözlemler başlıklı eserinde "Afrika siyahlarının doğadan zeka almadıklarını ileri sürmüştür”. Hegel, "siyahların insanlığın yüz karası olduğunu ve Afrika'nın Dünya Tarihi'nin bir parçasını oluşturamayacağını çünkü bu yönde herhangi bir gelişme sergilemediğini" Tarih Felsefesi başlıklı yapıtında belirtmiştir" (Taş, 1999'dan Akt. Aktaş, 2014: 44). Bu tür düşünceleri referans alan bat1, kapitalizmin etkisiyle de yaptığ1 sömürgeciliğini birçok alanda gerçekleştirmiştir. Sömürge ülkelerinin dili, dini, yaşam biçimleri ve daha pek çok yaşam pratikleri kökten tahrifata uğramıştır. $\mathrm{Bu}$ tahrifatta Batının medya emperyalizmi önemli rol oynamıştır. İdeolojik temelde meşruiyet kazandırma, insanların öz bilgisini tahrif etme ve onları özneleştirerek dengesiz haber ağına sahip haber ajanslarının gelişmekte olan ülkelere tek yönlü enformasyon akışı sağlaması medya emperyalizme yol açar. Bunun ideolojik zeminini ise (Althusser, 2010)'in vurguladığı gibi "her ideoloji ancak bir özne aracılığı ile ve özneler için var olabilir” sözünde bulunabilir.

"Emperyalizm, sözcük anlamı olarak, ulusların siyasi ve askeri güç kullanarak diğer ulusları istila etme ve sömürgeleştirme sürecidir. Buna karş1lık olarak, medya emperyalizmi de, ulusların medya iletişimini kullanarak diğer ulusların kültürel değerlerini denetim ve tahakküm altına alma sürecidir. Son yıllarda Amerikan medya emperyalizmi tüm dünyayı kanatları altına almayı başarmıştır. Ülkenin popüler müziği, Hollywood filmleri, Frasier ve 24 gibi başarılı televizyon dizileri dünyanın her yerinde satmaktadır" (Laughey, 2010: 7475). “1983 ve 1993 yılları arasında, ABD' nin medya hizmetleri ihracı, \%90 artış göstermiş olan toplam hizmet ihracatıyla karşılaştırıldığında, \%138 artmıştır. ABD' nin medya malları ihracı ise $\% 201$ artmış, buna karşın toplam mal ihracı \%110 artış 
göstermiştir" (Petras ve Yeltıneyer, 2006: 205). "Büyük ajanslar, ayrıca, faaliyetlerini çeşitlendirmiş ve genişletmiştir. Bunda, onların enformasyon ve iletişim teknolojisindeki yeni gelişmelerin avantajlarını kullanmalarının, finansal ve ticari işlemlerle ilgili enformasyonu kapsayan değişik veri ve enformasyon türlerine yönelik küresel pazarda merkezi oyuncular olarak ortaya çıkmalarının payı vardır. Uluslararası enformasyon ve iletişim akışındaki diğer eşitsizliklerle birleştiğinde, yeni büyük ajansların egemenliği, küresel enformasyon düzeninin yeniden örgütlenmesine dönük çeşitli çevrelerden çağrılar gelmesine yol açmıştır" (Thompson, 2008: 237-238). Medya dolayımılla içerikleri alımlayan tüketici konumundaki ve yeterince alternatif medya kaynaklarına sahip olmayan insanlar, kendilerine sunulan eğlence enformasyonlarıyla birlikte arka planda bir tür örtülü ideolojiyi de alımlamak durumunda kalmaktadırlar ve medyanın bu sistemli aygıtı durmamacasına işlemektedir.

"Küreselleşmenin temel aracı olan medyanın eleştirel işlevlerine baktığımızda, genel olarak, pazar ekonomisi mantığına göre yayın yaptığını ve toplumda yarattığı etkinin, yönlendirme, kullanma, pasifize etme, aktifleştirme, değiştirme, parçalama, birleştirme eylemlerine yönelik olduğu görülmektedir" (Mora, 2008: 79). "Böylece, kitle iletişim araçlarını kontrol altında tutunca, küresel pazara uyumun şartlarını yaratıyorsunuz ve ona karşı etkili bir direniş olasıllğını sinırlyyorsunuz" (Saadawi, 2007: 201). Bu durum da emperyalizme maruz kalan ülkeler için sermayenin ideolojik aygıtı olan dengesiz haber akışı, dezavantaj oluşturarak ülkelerin kendi yönünü tayin etmelerini olumsuz etkilemektedir. $\mathrm{Bu}$ bağlamda haberleşme DİA'sı ideolojik olan her şeyin gerek yaratımında gerekse de dağıtımında başat role sahiptir.

Kültürel emperyalizm/medya emperyalizmi kuramına göre, gelişmiş ülkelerin egemen kültür ve değerlerinin medya yardımı ile diğer ülkelere empoze edildiği, özellikle televizyon programlarının, üçüncü dünya ülkelerinin kültürel değerlerinin tahrip edilerek, Amerikan/Batılı kültürel değerlerinin egemen kılınması amacıyla kültür endüstrisi tarafından, bilinçli bir şekilde, seri, tek tip ve yapay olarak ürettiği ürünlerin, tek yönlü olarak akmasıyla, o ülke vatandaşlarının kapitalist değer ve amaçlarını benimsemesine ve kendi değerlerine yabancılaşmasına neden olduğu varsayılmaktadır. Küreselleşme kapsamında, kapitalist üretim anlayışı çerçevesinde gelişen çokuluslu şirketler, ürettikleri ürünler aracılığı ile tüketimi pompalamakta, kendi ideolojilerini, yaşam ve eğlence kültürlerini tek yönlü ve kendi çıkarları doğrultusunda az gelişmiş ve gelişmekte olan ülkelere doğru akıtmaktadırlar (Mora, 2008: 79). Uluslararas1 haber ajanslarının ideolojik bir aygıt gibi çalışması gelişmemiş ülkeler üzerinde bir takım olumsuz gelişmelere sahne olmuştur. $\mathrm{Bu}$ olumsuzlukları durmamacasına ve genelde tek yönlü olarak vermek suretiyle uluslar, toplumlar veya insanlar arasında yeni ideolojilerin türemesine ve bazı sınırsızlıklara neden olmuştur. Bunları Özyurt şöyle sıralamaktadır; 
- Tüketim ve kitle kültürünün yayılması,

- Kültür emperyalizmi endişesi,

- Yaşam tarzlarının küreselleşmesi,

- Ulusal kültür ve kimliğin zayıflaması,

- Küresel sorunlardan haberdar olma ve küresel bilinç,

- Uzak yerlerle haberleşmenin kolaylaşması ile yeniden yerelleşme,

- Avrupa kimliği gibi, ulus-üstü bölgesel kimlikler,

- Küresel kültür çatışmaları (2012: 141).

\section{Uluslararası Haber Ajansları}

Oxford sözlüğüne göre Latince "agentia" kelimesinden gelen ve 17. yüzyılın ortalarına kadar kelime kökenine gidilen ajans (agency) kelimesi bir iş, kişi ya da bir grubun adına hizmet veren özel bir işletme veya organizasyon anlamına gelmektedir (www.oxforddictionaries.com, 2020). Haber ajans1 da Türk Dil Kurumu Sözlüğüne göre; "yurt ve dünya olaylarını toplayıp yayımlayan kuruluş" (www.tdk.gov.tr, 2020) ${ }^{1}$ olarak tanımlanmaktadır. "Değişik anlamlar içermesine rağmen, ajans kelimesinin ağırlıklı anlamı haberle bağlantılıdır. En kısa anlatımıyla haber üreticileri de denilen haber ajansları, haber niteliği taşıyan gelişmeleri, olayları (eylem ya da söylemleri), en kısa süre içinde derleyerek ilgili kuruluşlara ya da ilgililere iletirler" (Girgin, 2002: 109). "Bütün tanımlamalardan, haber ajansının haber toplama ve yazma işlevleriyle uğraştığı, gördüğü hizmeti de belirli bir ücret karşılığ1 sattığ1 görülebilmektedir. Günümüzde haber ajansları haber ya da haber için gerekli olan malzemeleri yazılı, görüntülü, sesli haber üretme yanında dijital haber ve eğlence haberi de üretmektedir. Aynı zamanda, haber ajansı ürettiğ haberleri müşterilerine ve abonelerine dağıtarak satmaktadır" (Tokgöz, 2015: 213).

Uluslararası haber ajansları temelde haber duyurma işlevleri dolayısıyla önemli kuruluşlardır. Günümüzde yaklaşık 8 milyarı bulan dünya nüfusunun ihtiyaçlarından biri haline gelen haber erişiminde ulusal ve uluslararası haber ajansları etkin rol oynamaktadır. Gelişkin teknolojiyi kullanan haber ajansları en hızlı biçimde haber tüketicilerine enformasyon sağlayabilmektedirler. Yapay zekâ teknolojisinin de artık haberleşme alanında yer edinmeye başlamasıyla birlikte bu teknolojiyi hem haber ajansları hem de enformasyon hedef kitlesi kullanmaktadır. Bütün bunlardan ziyade en önemli şey, gazetecilik meslek etiğine sahip çıkılarak, dürüst ve doğru haberi tüketicilere ulaştırmaktır.

“16. yüzyıldan itibaren dünyanın büyük kısmını askerî güçleriyle sömürgeleştiren Batı, 19.yüzyılın ilk yarısında kurduğu haber ajanslarıyla da dünyayı paylaşmıştır. Günümüzde ise, sömürge ülkeleri yakın geçmişte bağımsız ülkeler durumuna gelse de, sömürgecilik bitmemiş, biçim değiştirerek devam etmektedir. Hatta

\footnotetext{
${ }^{1}$ https://sozluk.gov.tr/ (Erişim Tarihi: 19.09.2020).
} 
hızla gelişen iletişim teknolojisi ile gittikçe küreselleşen dünya üzerindeki Batı'nın egemenliği genişlemekte ve pekişmektedir. Zira sömürgeciliğe doğrudan maruz kalmayan, derin ve köklü tarihe ve kültüre sahip ülkeler üzerinde de Batı'nın biçim değiştiren egemenliği yayılmaktadır. Yalnız bu egemenlik askerî işgallerle değil, siyasî, ekonomik, ticarî ve kültürel olarak gerçekleştirilmektedir. Batı'nın günümüzde tüm Batı dışı toplumlar üzerinde sürdürdüğü böyle bir egemenliğinin en temel aracı kurduğu uluslararası iletişim düzenidir" (Zorlu, 2016: 846).

Kapitalist dünya sistemi özünde sürekli güçlenmeyi ve gücü tek elde tutabilmeyi amaçlamaktadır. Bu durumdan payını haber ajansları da almıştır. Ve dünya ölçeğinde sayılı uluslararası haber ajansı bulunmaktadır.

Thompson, 2008'e göre ilk haber ajans1 "1835'te Charles Havas tarafından Paris'te kurulmuştur. 1840'a kadar at arabaları ve düzenli güvercin postası sayesinde, Londra ve Brüksel'deki müşteriler için de haberler sağlanmıştır. 1840'ların sonlarında Londra' da Paul Julies Reuter ve Berlin'de Bernard Wolf rakip haber toplama servisleri kurulmuştur. Ajanslar, enformasyonu o zamana kadar görülmedik bir hizda ve mesafede kat ederek ileten telgraf kablo sistemlerindeki gelişmenin avantajından yararlanmıştır. Her üç ajans da yeni müşteri kazanmaya ve çalışma sahalarını genişletmeye çaba gösterdikleri için, 1850 'de aralarındaki rekabet yoğunlaşmıştır. Ancak çatışmanın zararlarından kaçınmak isteyen bu ajanslar, en nihayetinde dünyayı özel çalışma bölgelerine bölme konusunda işbirliği yapmayı kararlaştırmışlardır. 1869'daki Ajans Birliği Anlaşması'na göre, Reuter, Britanya imparatorluğu ve Uzak Doğu'daki; Havas, Fransız İmparatorluğu, İtalya, İspanya ve Portekiz'deki bölgeleri paylaşmıştır. Wolfe ise Almanya, Avusturya, İskandinavya ve Rus topraklarında özel çalışma ayrıcalığı tanınmıştır. Her ne kadar bağımsız ticari örgütler olsalar da, ajansların çalışma alanları, büyük Avrupa emperyal güçlerinin ekonomik ve siyasi nüfuz sahalarına denk gelmiştir. Ticaret ve diplomatik idare için değerli enformasyon sağlayan ve bir ölçüde politik himayeden yararlanan her ajans, ana üs olarak hizmet ettikleri ülkenin siyasal ve ticari elitleriyle işbirliği yapmıştır".

“1869’dan başlayarak 1870’li yıllarda Havas, Reuter, Wolff ve Viyana’da kurulu Korrbureaun arasında yeni işbirliği anlaşmaları imzalanmıştır. Bu anlaşmalara göre, Avusturya Ajansı yerel niteliğinde kalmış; Havas ve Reuter, kar ve zararda ortak işletmeler kurmuşlardır. Bunlar Fransa'da Havas, Laffitte, Bullier; İngiltere'de Reuter; öteki ülkelerde ise Havas-Reuter ya da Reuter-Havas adlarını kullanmışlardır. Önemli olan, imparotorlukların dünyanın topraklarını paylaştıkları 
bir dönemde, üç ajansın da dünyayı haber yayma tekeli açısından bölüşmeleridir" (Girgin, 2008: 75). “1869'daki Ajans Birliği Anlaşması'na göre, Reuter, Britanya imparatorluğu ve Uzak Doğu'daki; Havas, Fransız İmparatorluğu, İtalya, İspanya ve Portekiz'deki bölgeleri paylaşmıştır. Wolf'e ise Almanya, Avusturya, İskandinavya ve Rus topraklarında özel çalışma ayrıcalığı tanınmıştır. Her ne kadar bağımsız ticari örgütler olsalar da, ajansların çalışma alanları, büyük Avrupa emperyal güçlerinin ekonomik ve siyasi nüfuz sahalarına denk gelmektedir. Ticaret ve diplomatik idare için değerli enformasyon sağlayan ve bir ölçüde politik himayeden yararlanan her ajans, ana üs olarak hizmet ettikleri ülkenin siyasal ve ticari elitleriyle işbirliği yapmıştır" (Thompson, 2008: 235-236). Enformasyonun bu ülkelere sürekli olarak ve tek yönlü olarak akması, istenilen ideolojinin yine bu ülkede tohumlarının ekilmesi anlamını taşımaktadır.

"Uluslararası enformasyon akışındaki tek yönlülük eşit olmayan bir dünya iletişim düzenini de beraberinde getirmektedir. $\mathrm{Bu}$ eşitsizlikte etkilenen taraf ekonomisi zayıf, iletişim teknolojileri kısıtlı ve dünyanın büyük çoğunluğunu oluşturan yoksul ülkeler, etkileyen taraf ise ekonomisi güçlü, her türlü iletişim teknolojilerine sahip ve dünyanın çok az nüfusunu oluşturan gelişmiş kapitalist ülkelerdir" (Enserov, 2010: 72). "Dünyanın herhangi bir ülkesinde gelişen bir olayla ilgili bilgilerin, örneğin AP'nin New York bürosuna ulaşması için 2 dakika yeterlidir. Ama tüketici kültürlerin bu habere ulaşmaları tümüyle AP'ye bağlıdır. Haberi hiç dağıtmayabilir, ya da istediği zaman ve istediği biçimde verebilir. Örneğin önemli bir hükümet darbesini kısa bir haber olarak, İngiltere prensesinin ayrıntılı doğum haberinden ya da güzel bir artistin özel yaşamıyla ilgili haberden sonra verebilir" (İlal, 2007: 89). Medya emperyalizmi enformasyon sömürgeciliği yaptı̆̆ ülkelere çeşitli şekillerde ve farklı amaçlar altında bir takım kültürel ve anlamsal yayılmacılık yapmaktadır. Bunlar bazen kavramlar olabileceği gibi bazen de örf ve adetlere yönelik olabilir. Henüz toparlanma aşamasına bile geçememiş ülkelerde yaşayan insanlar kendi ontolojik kabuklarından çıkmadan toplum mühendisliği gibi operasyonel müdahalelerle haberleşme DİA's1 ile belli bir ideoloji zemininde yönlendirilmektedirler.

"Elektronik aygıtlar aracılığıyla haber iletme unsurunun kendi şartları vardır. Her şey yaratacağ ${ }_{1}$ etkiye göre hesaplanır. Yani bu alanda haber iletme yaratacağ etki peşinen hesaplanarak yapılır. Buna isterseniz "kandırma" diyebilirsiniz" (Özel, 2015: 196).

Diğer yandan haberlerle, reklam ve tüketim olgusu da içi çe girmektedir. İlal'e göre "ünlü bir Amerikalı yıldızın sigara içmekten ve tenine blue-jean giymekten çok hoşlandığına ilişkin bir haberin tüketici kültürüne itilmesi, hem ünlü yıldızın hem sigara içilmesinin ve blue-jean giyilmesinin etkili bir reklamını oluşturmaktadır" (2007: 92). Bu nedenle bir malın tüketiminin, ya da bir yaşam biçiminin çok tutulduğuna, "moda" olduğuna ilişkin haberlerin üretilmesinde, araçlararası tekelleşmeler içine girmiş yığınsal iletim sermayesi, reklam şirketleri 
ve haber ajansları arasında karmaşık bir ilişki doğmuş bulunmaktadır ve hediye bir malın sunulması kavramıla, yalan ya da yanlış haber üretmek arasındaki çizgi tümüyle aşınmış durumdadır (İlal, 2007: 92-93). İdeolojik aygıtın yer edinmesinde reklam payının ne olduğunun iyi anlaşılması gerekir. Her reklam ürünü kendisinin en iyisi olduğu vurgusuyla ortaya çıkar. Bu suretle insanların zihninde ideolojik bir güç yaratımı oluşturulmaya çalışı1ır. Bunun için yerel düzeyden alın uluslararası düzeye değin her şeyin reklam için kullanılması mübahtır ve bunu farklı uluslarda insanların zihinlerine taşıyanlar arasında haber ajanslarının reklamla olan karmaşık ilişkisidir. Dolayısıyla reklam eğlendirerek ideolojiyi insan algısına yerleştirir.

Reklamların çoğu zaman halka, (alıcıya), becerikli yapımcılara ve böylelikle ulusal ekonomiye yararlı bir yarışma aracı olduğu savunulur. Özgürlükle çok yakından ilgili bir savdır bu: alıcının seçme özgürlüğü, üreticinin girişim özgürlüğü gibi özgürlüklerle kapitalizmin egemen olduğu kentlerde tüketim maddelerinin oluşturduğu büyük yığınlar ve reklam 1şıkları, özgür dünyanın sunduğu hemen göze çarpan görsel imgelerdir. Reklamlarla her birimize bir nesne daha satın alarak kendimizi ya da yaşamlarımızı değiştirmemiz önerilir (Berger, 2013: 130-131). Böylece alınan bir nesne, alan da özne olarak yer alır. Bu bir tür medya emperyalizmidir. Tüketim toplumu oluşturmak için bireylerin bilinçlerine nüfuz eden ve bu ideolojiyi daha çocukken aile ve okul gibi kurumlardan alarak yetişen bireyler sürekli enformasyon karşısında özneleştirilerek aslında üretimin yeniden üretilmesine de olanak tanıyabilmektedirler.

Boyd-Barrett 1970'lerde Marksist siyasal ekonomi temelli "medya emperyalizmi” teziyle gündeme gelmiştir. Boyd-Barrett'e göre (1977) "medya emperyalizmi iki önemli uluslararası medya faaliyeti biçimlerini anlatır:

1) Uluslararası tek yönlü medya akışı: bu akışta Amerika'ya olan akış yok denecek kadar azdır.

2) Birkaç ülke (Amerika, İngiltere, Fransa, Almanya ve Rusya) uluslararası medya nüfuzuna (etkisine) sahiptirler."

"Boyd-Barrett'e göre medya emperyalizmi, herhangi bir ülkedeki medya sahipliği, yapısı, dağıtım veya içeriğinin tek başına veya birlikte, diğer ülke veya ülkelerin medya çıkarlarının önemli miktarda dış baskısına maruz kalması sürecidir. $\mathrm{Bu}$ süreçte kültürel işgalde güç dengesizliğinin varlığ emperyalizm kavramını kullanmayı haklı çıkartır. Bu durum uluslararası medya faaliyetlerinin incelenmesini ve bununda uluslararası ekonomik ve siyasal ortam ve tarih içinde yapılması gerekliliğini ortaya çıkartır" (Erdoğan ve Alemdar, 2005: 395).

"Haber ajansları, 19. yüzyılın ilk yarısında, salt haber toplamak, üretmek ve yaymak, dolayısıyla kamuoyunu aydınlatmak gibi işlevlerin yanı sıra bir yönüyle ulusal gereksinimler, ağırlıklı olarak da uluslararası ticaretin gelişmesi sonucu kurulduklarından, küreselleşmenin (farklı ulusal ekonomilerin, uluslararası ticaret 
ve mali piyasayla birbirlerine bağlanmaları) ilk gözle görülen kanıtları olmuştur" (Girgin, 2008: 69). "Özellikle çok uluslu şirketlerin faaliyetinin bir ürünü olan batıya ait haber ajanları tüm dünya üzerinde hegemonyasını kurmuştur. Olaylar bu haber ajanslarının bakış açısıyla aktarılmaktadır" (Kasap, Dolunay ve Mırçık, 2018: 524). Batılı ülkelerin kuruluşları olduğu için haber toplama ve yayma işinde, bağlı oldukları ülkelerin görüşleri veya talepleri doğrultusunda çalıştıkları gerekçesiyle eleştirilen, ancak organizasyonlarının büyüklüğü ve işlevlerinin boyutu nedeniyle alternatifsiz çalışmalarını sürdüren uluslararası haber ajansları şunlardır (Rigel, 2000: 81): "Reuters, merkezi Londra'da bulunan haber ajansıdır. AP (Associated Press), Amerika Birleşik Devletleri merkezli haber ajansıdır. UPI (United Press International), merkezi Amerika Birleşik Devletleri'nde bulunan haber ajansıdır. AFP (Agence France-Presse) Fransa kökenli haber ajansıdır. TASS merkezi Moskova'da olan uluslararası haber ajansıdır".

\subsection{Reuters}

"İlk haber ajansı 1835 'te Charles Havas tarafindan Paris'te kurulmuştur" (Thompson, 2008: 235). Reuters ise, “1851'de daha önce Havas Ajansı'nda çalışan Poul Julius Reuter tarafindan İngiltere'de kurulmuştur. İlk yıllarında İngiltere'nin dışındaki ülkelere telgraf hattıyla haber ulaştıran Reuters, daha sonra kablo sistemlerinin gelişmesiyle Avrupa'da etkinliğini artırmıştır' (İnuğur, 1993'den Akt. Çakır, 2007: 157). "Reuter'in ajansı, kısa süre içinde en yoğun uluslararası elektrik kablosu ağlarının da çıkış noktası olacak olan, ticari ve mali işler açısından dünyanın en canlı kentinde bulunmanın avantajıyla, hemen ilerlemiştir" (Jeanneney, 2006: 101).

"Hem teknolojik olanakları elinde bulundurmak hem de bu olanaklara uygun haber hizmeti sunmak bakımından, Sovyetler Birliği'nin parçalanmasından ve 1991 yılı başındaki Körfez savaşından sonra, üç Batılı haber ajansı olan Associated Press, Reuters ve Agence France Presse söz sahibi durumdadır. Anılan üç büyük haber ajansı dünyadaki iletişim akımını düzenlemek, ona yön vermek için büyük bir yarış içindedir. Bu yarış giderek her gün daha büyük boyutlara ulaşmaktadır. Dünyanın iletişim yönünden gündemini belirlemek için büyük çaba sarf edilirken, hiç kuşkusuz küreselleşme yönünden katkıları ve etkilerini dikkatten uzak tutmamak gerekir" (Tokgöz, 2015: 211). Reuters haber ajansı bugün AccuWeather, Aflo, Africa24 Media, BBC News, Custom Weather, Field Level Media, Hollywood TV, Ivanhoe Broadcast News, Jukin Media, Medpage Today, Next Animation Studio, Opta, Panoramic, Perform Content, Pixathlon, Red Bull Media House, Scanpix, USA Today Sports ve Variety ile işbirliği içerisinde yer alarak dünyanın iletişim yönünden gündemini belirleme gücünü elde etmesinin yanı sıra alternatif olabilecek medya kuruluşları ile koordineli çalışarak çok sesliliğin de önüne geçmektedir. 


\subsection{AP (Associated Press)}

1846 'da, New York şehrinde yayın yapan beş gazete, ABD'deki postanenin gönderebileceğinden daha hızlı bir şekilde Meksika Savaşı'nın haberi için Alabama'nın tamamını kapsayacak şekilde haber toplama kooperatifi kurmuştur (www.ap.org, 2020). “Associated Press bugün dünyada var olan haber ajanslarının devamlılık yönünden en eskisidir. Kuruluşu 1848’e kadar giden Associated Press, Amerikan gazetelerinin sahip bulunduğu bir kooperatif şeklinde örgütlenmiştir. Associated Press'in merkezi ABD'nin New York kentindedir' (Tokgöz, 2015: 222).

AP'nin dünya çapında çalışan 3700 muhabiri bulunurken, 300'den fazla haber merkezine hizmet götürülmektedir. Eskimiş olan sınırlı uydu şebekesini devre dişı bırakan AP, 2010 yılı sonundan itibaren Amerikan gazetelerine online hizmet vermeyi başlatmıştır. "AP, uluslararası haber ajansları arasında en büyük ve en etkin haber ajansı olmayı sürdürmektedir" (Tokgöz, 2015: 222). "Bugün 100 ülkede 250 'den fazla lokasyonda günlük 2 bin haber, y1llık 70 bin video ve y1llık 1 milyon fotoğrafla hayatına devam etmektedir (www.ap.org, 2020) Ayrıca AP, Yapay zekaya ilk yatırım yapan kuruluşlardan biridir, kullandığı uygulama sayesinde her gün finans haberleri geçtiği kurum sayısını 300'den dört bine çıkarmıştır" (www.gazeteduvar.com.tr, 2020).

\subsection{UPI (United Press International)}

UPI, 1907 y1linda United Press (UP) olarak E.W. Scripps tarafindan kurulmuştur. 1959'da William Randolph Hearst tarafindan kurulan 1958'de Uluslararası Haber Servisi ile birleştikten sonra UPI olarak tanınmıştır. Bugün, UPI News World Communications'a aittir ve Washington, DC, Boca Raton ve Florida merkezli çalışmaktadır (www.upi.com, 2020). "Kuzey Amerika'nın yanı sıra güney Amerika ve Avrupa'daki gazetelere haber akışı sağlamıştır. Dünyada, özel kişilere ait olarak kurulan en büyük haber ajansı olma özelliğini taşımaktadır. ABD'de AP'nin en büyük rakibi durumundaki UPI, AP'nin yazılı basındaki ağırlığı karşısında daha çok radyo ve televizyon kuruluşlarından destek görmüştür. UPI'nin 90 ülkede 180 bürosu bulunmaktadır" (Çakır, 2007: 158).

\subsection{AFP (Agence France-Presse)}

AFP'nin kendi kurumsal sitesinden ulaş1lan bilgiye göre; "Charles Havas, Agence Havas'1 1835'de kurmuştur. Dünyanın ilk uluslararası haber ajansı olmasına karşın, muhabirler ve tercüman ağı oluşturmuştur. Charles Havas, haberleri devlet servislerinden daha hızlı yayınlamak için posta güvercinleri kullanmıştır. Ajans, genişlemesini sağlayan bir buluş olan elektrikli telgrafları 1845 yılında kullanmaya başlamıştır. 1880'den itibaren Telefon, teletype ve uzun dalga telsizin devreye girmesiyle gazetecilerin çalışma şeklini değiştirmiş ve bu yeni yayın araçları Fransa'da basının gelişimi sayesinde haber miktarını oldukça artırmıştır. Agence Française Indépendante (AFI) 1940 y1lında Paul-Louis Bret tarafindan Londra'da kurulmuştur. Daha sonra OFI, Agence France-Presse adını 
alarak AFP doğmuştur. Günümüzde AFP, bin 700 gazeteci ve 2 bin 400 personelle 100 farklı ulusa 151 ülkede 201 büroyla ve 6 farklı üretim diliyle yayın hayatını sürdürmektedir. Bunun yanı sıra AFP'nin bazı ortakları şunlardır: Busıness Wıre, Agência Estado, Agıf, Anadolu Agency, Bangkok Post, Biosphoto, Bnf, Brazıl Photo Press, Bsip, Capgemını, Christophel, Controluce, Cultura Creatıve, Current Affarrs In The Arab World, Dpp1, Eqs Group, Eyepress, Foodcollection, Getty Images, Globenewswire, Hans Lucas, Hemis, Higbee \& Associates, Image Law, Image Source, Imaginechına, Impıre, Ina, India Today Group, Infostrada Sports, Leemage, Mauritıus Images, Mexsport, Mintımages, News Aktuell, Notımex, Nurphoto, Only France-Only World, Parıs Modes, Phanıe, Photo Alto, Photo12, Photononstop, Photosport, Picrights, Pr Newswire, Presse Sports, Qmı Agency, Relaxnews, Rmn-Grand Palais, Robert Harding, Roger-Viollet, Science Photo Library, Singapore Press Holdıngs, Sooc, Sputnık, Studıo Harcourt, Temıs, The Times Of India, The Yomıurı Shimbun, ve Xinhua News Agency" (www.afp.com, 2020).

\subsection{TASS}

TASS haber ajansının gelişmesi ise şöyle olmuştur; "Rusya'nın ilk resmi haber ajans1 ve ITAR-TASS'in selefi olan St. Petersburg Telgraf Ajans1 (SPTA) 1 Eylül 1904'te faaliyete geçmiştir. 19 Ağustos 1914'te SPTA adını değiştirmiş ve Petrograd Telgraf Ajansı (PTA) olmuştur. 7 Eylül 1918'de hükümet, PTA ve Basın bürosunun adını Rusya Telgraf Ajansı (ROSTA) olarak yeniden adlandırmaya karar vermiştir. 10 Temmuz 1925 'te Sovyetler Birliği'nin Telgraf Ajansı (TASS) kurulmuş ve ülkenin merkezi bilgi ajansı olarak Rus Telgraf Ajansı'nın temel işlevlerini devralmıştır. TASS, tüm Sovyet cumhuriyetlerinin haber ajanslarından oluşuyordu: RATAU (Ukrayna), BELTA (Beyaz Rusya), UZTAG (Özbekistan), KAZTAG (Kazakistan), GRUZINFORM (Gürcistan), AZERINFORM (Azerbaycan), ELTA (Litvanya), ATEM (Moldavya), LATINFORM (Letonya), KIRTAG (Kırgizistan), TAJIKTA (Tacikistan), ARMENPRESS (Ermenistan), TURKMENINFORM (Türkmenistan), ETA (Estonya). Sovyetler Birliği döneminde TASS' 1 h haber ve fotoğrafları 4.000 Sovyet gazetesi, TV ve radyo istasyonu ile binden fazla yabancı medya kuruluşu pazarına sahip olmuştur. TASS, Sovyetler Birliği'nin çöküşünden ve egemenliğin demokratik Rusya tarafından ilan edilmesinden sonra Ocak 1992'de Rusya Bilgi Telgraf Ajansı (ITAR-TASS) olarak isimlendirilmiştir. Eylül 2014'te, ajans eski ve dünyaca ünlü ismine TASS olarak geri dönmüştür (www.tass.com, 2020).

\section{Sonuç}

$\mathrm{Bu}$ makalede uluslararası düzeyde yer alan haber ajansların uluslararası enformasyon ağında tek yönlü akış ile haber sağladıklarına, bu haberler içerisinde kendi duygu ve düşünce ve ideolojilerini de bir şekilde açıktan veya gömülü olarak servis ettiklerine, bunu yaparken Althusser'in belirttiği şekliyle haberleşmeyi bir 
aygit biçimiyle kullanabilecek güce ve potansiyele sahip olduklarına dikkat çekilmiştir.

$\mathrm{Bu}$ çalı̧̧madan yola çıkarak dikkat edilmesi gerekilen hususlar ve sonuçlar aşağıda özetlenmiştir. Beş büyük uluslararası haber ajansının dünyanın neredeyse tamamında enformasyon aktörü olarak yer alması dengesizliğin başat belirleyenidir. $\mathrm{Bu}$ dengesizliğin ideolojik eksenli medya emperyalizmi yarattığ 1 gerçeği de göz ardı edilemez. Sürekli enformasyon bombardımanına maruz kalan az gelişmiş veya yetirince haber ağ gelişmemiş ülkelerin fikir ve tasavvur olarak savunmasız kalmaları söz konusudur. Bundan dolayı bireylerin haber ihtiyaçlarını karşılarken olabildiğince eleştirel bir bakış açısıyla ve çok farklı haber kaynaklarını karşılaştırarak konuyu irdelemeleri gerekmektedir. Ayrıca uluslararası haber ajansları ellerinde bulundurdukları imkânlar doğrultusunda hangi haberin verileceği hangisinin verilmeyeceği konusunda seçici davranabilmektedirler. Toplumu/insanlığı yakından ilgilendirecek konular görmezden gelinebilmektedir. $\mathrm{Bu}$ da tam olarak haber akışındaki dengesizliğin ne kadar büyük bir sorun olduğunu göstermektedir. Bununla birlikte çalışmada incelenen haber ajanslarının halen dünyada en büyük haber ajansları olmaları dolayısıyla haber akışındaki dengesizlik sorununun devam ettiği sonucu çıkarılabilir.

Sonuç olarak uluslararası beş büyük haber ajansının büyüklüğüne ve dünyada kapladığı alana bakıldığında dünyanın bir yerinde meydana gelen olayın önemi, haber ajanslarının o olaya hangi perspektiften baktıklarıyla yakından ilişkili olduğu saptanmıştır. Uluslararası haber akışında medyanın bilgilendirme işlevi önemli bir kamu hizmetidir, tabi doğru kullanılırsa. Aynı zamanda bu durum sermaye iktidarının haberleşme DİA'sını nasıl kullanmak istediğiyle de ilgili olmuştur. Ayrıca çalışmada yukarıda bahsedilen haber ajansların sermaye iktidarıyla akrabalığını göstermesi açısından çeşitli kurum ve kuruluşlarla pek çok ortaklıklarının da olduğu da saptanmıştır. Haberleşme aygıtı en hızlı, en kapsamlı ve sürekliliği bakımından herkesin rahatça ulaşabileceği bir konuma sahiptir. Bundan dolayı ideolojinin aşılanmasında, yerleşmesinde bireyleri özneleştirerek çağırmasında haberleşme aygıtına olan ihtiyaç yadsınamaz bir güç olarak durmaktadır. Dolayısıyla insanlar haber ihtiyaçlarını karşılarken daha dikkatli, duyarlı ve ön yargılı yaklaşmaları gerekmektedir.

\section{Kaynakça}

AFP, Agence France-Press, https://www.afp.com/en/agency/afp-dates, (Erişim Tarihi: 05. 06. 2020).

Akdemir, Semra (2002). "Enformasyon Egemenliği”, Kurgu Dergisi, s:19: 239255. 
Aktaş, Murat (2014). “Avrupa'da Yükselen İslamofobi ve Medeniyetler Çatışması Tezi”, Ankara Avrupa Çalışmaları Dergisi, 13 (1): 31-54.

Althusser, Louis (2010). İdeoloji ve Devletin İdeolojik Aygitları. (Çev. Alp Tümertekin ) İthaki Yayınları: İstanbul.

Althusser, Louis (2014). İdeoloji ve Devletin İdeolojik Aygitları. (Çev. Alp Tümertekin ) İthaki Yayınları: İstanbul.

AP, Associated Press, https://www.ap.org/about/our-story/, (Erişim Tarihi: 29.05.2020).

Berger, John (2013). Görme Biçimleri, Metis Yayınları: İstanbul.

Çakır, Hamza (2007). Gazeteciliğe Giriş, Tablet Yayınları: Konya.

Çelik, Nur Betül (1999). "İdeoloji Kuramlarında Özne: Althusser Ve Gramsci”, Kültür ve Illetişim”, 2(2): 101-128.

Çoban, Savaş (2011). Hegemonya Aracı Ve İdeolojik Aygit Olarak Medya, Marmara Üniversitesi Sosyal Bilimler Enstitüsü İletişim Bilimleri Anabilim Dalı Radyo TV Bilim Dalı, İstanbul.

Dikici, E. (2014). "Doğu-Batı Ayrımı Ekseninde Oryantalizm ve Emperyalizm”, Tarih Kültür ve Sanat Araştırmaları Dergisi, 3(2): 45-59.

Enserov, Vefalı (2010). "Uluslararası Enformasyon Akışında Etkilenen Taraf Olarak Azerbaycan'ın Durumu”, Erciyes Üniversitesi Iletişsim Fakültesi Akademik Dergisi, 1(3): 71-85.

Erdoğan, İrfan; Alemdar, Korkmaz (2005). Öteki Kuram: Kitle Illetişimine Yaklaşımların Tarihsel Ve Eleştirel Bir Değerlendirmesi, Erk: Ankara.

Foucault, Michel (2014). Özne ve İktidar: Seçme Yazılar 2. (Çevirenler Işı1k Ergiden-Osman Akınhay), Ayrıntı: İstanbul.

Gazetecilerin Yeni Asistanı: Yapay Zeka, (2018). https:// www .gazeteduvar .com.tr /teknoloji / 2018/ 07/25/gazetecilerin-yeni-asistani-yapay-zeka/, (Erişim Tarihi: 10.06.2020).

Girgin, Atilla (2002). "Haber Ajansı”, Selçuk Üniversitesi Iletişsim Fakültesi Akademik Dergisi, 2(2): 107-116.

Girgin, Atilla (2008). Gazeteciliğin Temel İlkeleri, Der Yayınları: İstanbul.

https://en.oxforddictionaries.com/definition/agency, (Erişim Tarihi: 21. 05. 2020).

İlal, Ersan. (2007). İletişim, Yığınsal İletim Araçları ve Toplum, Der Yayınları: İstanbul.

Jeanneney, Jean Noël (2006). Başlangıcından Günümüze Medya Tarihi. Yapı Kredi Yayınları: İstanbul. 
Karakoç, Sezai (2017). İslam'ın Dirilişis, Diriliş Yayınları (21. Baskı): İstanbul.

Kasap Fevzi, Dolunay Ayhan, Mirçık Ali Murat (2018). "Küreselleşmenin Medya Üzerinde Etkileri: Küresel Medyaya "Sürükleniş"”, Journal of History Culture and Art Research, 7(2): 515-532.

Kazanc1, Metin (2012). “Althusser, İdeoloji ve İdeoloji ile İlgili Son Söz”, İletişim Fakültesi Dergisi, 67-93.

Kazancı, Metin. (2002). "Althusser, İdeoloji ve İletişimin Dayanılmaz Ağırlı̆̆ı", Ankara Üniversitesi Sbf Dergisi, 57(01): 55-87.

Kazaz, Mete; Çoban, Melek. (2010). “Televizyon Haberleri Ve Egemen Söylemin Yeniden Üretimi Sürecinde İdeoloji İnşa Stratejilerinin Kullanımı”, Selçuk Üniversitesi Illetişim Fakültesi Akademik Dergisi, 6(2): 191-206.

Laughey, Dan (2010). Medya Çalışmaları: Teoriler ve Yaklaşımlar, Kalkedon Yayınc1lik: İstanbul.

Lenin, Vladimir (2003). Emperyalizm: Kapitalizmin En Yüksek Aşaması, Eriş Yayınları.

Marshall, Gordon (2005). Sosyoloji Sözlügü̈. (Çev. Osman Akınhay ve Derya Kömürcü), Bilim ve Sanat Yayınları: Ankara.

Mora, Necla (2008). Medya Çalışmaları Medya Pedagojisi ve Küresel İletişim, Altkitap.

Özel, İsmet (2015). Üç Zor Mesele: Teknik-Medeniyet-Yabancllaşma, TiYO Yayınc1lık: İstanbul.

Özyurt, Cevat. (2012). Küreselleşme Sürecinde Kimlik ve Farklılaşma, Açılım Kitap: İstanbul.

Petras, James; Veltmeyer, Henry (2006). Maskesi Düşürülen Küreselleşme, Mephisto Kitabevi, İstanbul.

Rehmann, Jan (2015). İdeoloji Kuramları Yabancılaşma ve Boyun Eğme Güçleri. Yordam Kitap: İstanbul.

Rigel, Nurdoğan (2000). Illeti Tasarımında Haber, DER Yayınevi: İstanbul.

Saadawi Nawal Ed (2007). Medya ve Savaş Yalanları Gerçekler Nasıl Karartıllyor (Ed. Lenora Foerstel), Yordam Kitap: İstanbul.

TASS, http://tass.com/history, (Erişim Tarihi: 30. 05. 2020).

Thompson, John Brookshire (2008). Medya ve Modernite, Kırmızı Yayınları: İstanbul.

Tokgöz, Oya (1981). Temel Gazetecilik. Ankara Üniversitesi Siyasal Bilgiler Fakültesi Yayınları: Ankara. 
Tokgöz, Oya (2015). Temel gazetecilik. İmge Kitabevi: Ankara.

UPI, United Press International, https://about.upi.com/, (Erişim Tarihi: 26. 05. 2020).

Williams, Raymond (2006). Anahtar sözcükler, İletişim Yayınları: İstanbul.

Yanardağoğlu, Eylem (2014). "Uluslararası Yayıncılıkta Değişen Pratikler: BBC Dünya Servisi Örneği”, Ankara Üniversitesi İlef Dergisi, 1(1): 11-31.

Zorlu, Yaşar (2016). "Uluslararası İletişim Düzeni ve Batı Egemenliği”, Journal Of International Social Research, 9(42): 846- 55. 